Dante with medicine. Though opposed to the view that Dante himself was a medical man, the professor stated that the poet studied medicine at Bologna, was closely connected with Alderotti and Pietro d'Albano, two of the most distinguished physicians of that time, was prior of the corporation of physicians and apothecaries, and was given the title of magister in a contemporary document.

Other papers on miscellaneous topics were those by Dr. F. J. Poynton on doctors and the dawn of aerostatia, by Dr. J. D. van Gils of the Hague on the doctors of Molière and Shaw, and by Mme. Panayotatou of Alexandria on hygiene and dancing in ancient Greece. It is proposed to hold the next Congress of the history of medicine at Geneva in 1925.

\section{The Research Association of British Rubber and Tyre Manufacturers.}

PROBABLY in no industry is the old ground of knowledge less thoroughly explored and the new unbroken field for useful research so extensive and attractive as in the rubber industry taken as a whole. A hundred years or a little more have passed since the discovery that rubber could be converted irito a workable form by solution in suitable solvents or by mechanical kneading, and the process of vulcanisation was discovered eighty years ago. These operations, which are yet applied unaltered in principle and very little different in practical detail still represent the foundation of rubber manufacture of the present day; compared with them, all the other innovations have been of minor importance. The disadvantages, however, inherent to these fundamental operations are so marked as to cause surprise that so little further advance has been made during the last half-century. It is almost astounding that so large a portion of the effective history of the industry should be found recorded in the remarkable "Personal Narrative " of Thomas Hancock, published in 1857 , after his retirement.

If anything further had been needed to emphasise the importance of the rubber industry, particularly that section of it dealing with the production of rubber tyres for various types of vehicles, and the call for its further scientific development, the period between I9I4 and I9I 8 supplied the necessary stress in an unmistakable manner. It was natural, therefore, that members of certain companies interested in the manufacture of rubber goods should decide to take advantage of the assistance offered by Government to found a Research Association of British Rubber and Tyre Manufacturers. An energetic Committee under the chairmanship of Mr. Alexander Johnson saw the Association pass from the embryo stage to a state of healthy and vigorous existence with Mr. B. D. Porritt as director of Research.

On account of the early part of the year 1920 being inopportune for the purchase of premises and equipment, the Research Association first found a temporary home in University College, London, thus enabling a commencement with a preliminary, albeit necessarily restricted, programme of work, more particularly of a purely physical and chemical nature. Later, after careful search and inspection of suitable premises, purchase was completed of two detached houses at I05 and IO7 Lansdowne Road, Croydon. These possessed several advantages, and after necessary alterations have been converted into a prepossessing unit. The space between the two houses is now occupied by a substantial connecting building which provides increased accommodation in addition to inter-communication. The frontage of the site is r 20 feet and the depth 206 feet, the latter leaving ample room for future extensions.

The building, which was formally opened by Lord Colwyn on July 26 , comprises administrative offices, library, experimental laboratory for the preparation of rubber, incorporation of compounding ingredients and vulcanisation, workshop, mechanical testing laboratory, physical laboratory, chemical laboratories, storage accommodation and caretakers' quarters. All the necessary heavy experimental plant is contained in the basement of the inter-communicating building, and one of the two original houses has been kept entirely free from running machinery in order to permit the use of delicate instruments without risk of disturbance from vibration.

Those responsible for the founding of this Association have realised that the importance of research to industry lies not so much in the possibility of very occasional discoveries of a revolutionary nature as in the sure benefits which are the abundant fruit yielded by the application of science to the improvement of existing methods. The functions of the Association, while not excluding the study of fundamental problems, include more prosaic considerations such as improvement in the control of manufacturing operations and the testing of raw materials and final products. In such directions there is indeed urgent need for work, such vital matters as the reasons for the use and selection of various necessary " compounding ingredients " and the methods adopted for the production of vulcanised rubber possessing special physical properties, e.g. resistance to cutting or abrasion, resilience, toughness or even hardness, being based on almost entirely empirical grounds, often of the least desirable type.

Whatever requirement may have to be left unsatisfied in such an Association as this, it should be able to anticipate with the utmost confidence an abundant and unceasing supply of problems for investigation.

D. F. T.

\section{University and Educational Intelligence.}

Prospectuses of Universities and Colleges for I922-23 are beginning to appear. Leeds University publishes an extensive programme of evening courses (advanced) in engineering, dyeing, textile and leather industries, and geology, and afternoon courses in coal-mining. During each of five evenings of the week from five to nine classes will be held. The faculty of engineering of the University of Bristol announces additional vacation courses to be held in r923. University College, Exeter, is establishing new courses, intermediate and final, in horticulture and in agriculture, the final course in agriculture being at the Seale-Hayne Agricultural College, Newton Abbot.

SECONDARY education in the United States is, as every one knows, conducted chiefly in public (that is to say, in State) schools. But the part of the field occupied by the private high schools and academies is not inconsiderable. Advance sheets from the biennial survey of education in the United States, I9I8-20 (Bulletin, I922, No. 9 of the Bureau of Education), show that in I9I9-20 there were 2093 of these institutions, attended by $184, \mathrm{r} 53$ secondary students and, in addition, 250,000 elementary pupils. A remarkable growth occurred between 1905 and 1920. During this period the number of their secondary students increased by 72 per cent. Nearly 75 per cent. of the institutions are under denominational control; of these 60 per cent. are Roman Catholic, and the following analysis shows that to the Roman Catholic schools is chiefly attributable the above-

NO. 2756 , vOL. I IO] 
mentioned increase in the number of secondary students in private schools. The increase wasin Roman Catholic schools from 20,150 to 76,054 ; in other denominational schools from 39 , 106 to 53,965 ; in non-sectarian schools from 47,95 I to 54,134 ; in all from 107,207 to $I 84, I 53$. The increase in the number of secondary students of negro race in private schools is also noteworthy-from 2774 in 1905 to 9526 in 1920. Less than half of the total number of these schools are co-educational, 385 being for boys only and 728 for girls only.

"WE should have a dynamic education to fit a dynamic world " is the burden of the address delivered by Dr. James Harvey Robinson, on " The Humanising of Knowledge," before the American Association for the Advancement of Science, at a meeting with the Pacific division in Salt Lake City on June 23-24. Once it was well to dehumanise science; now it must be rehumanised. Dr. Harvey thinks there is a real danger threatening the progress of science itself in neglecting the protest of philosophy, that the ideal of dehumanising scientific investigation loses sight of the fact that the onlooker is one of the essential elements in the observing and recording. The danger is not that the scientific ideal is faulty, but that mankind will not accept an idea unless it is attractive as well as true. "The politicians in the Kentucky legislature think themselves competent to decide whether the State should grant funds to any institution in which man's animal extraction is taught; the politicians in the New York legislature have provided that no one shall teach in the schools of the State who is known at any time to have expressed any distrust of our institutions." We on this side may smile at these fears; but after all it is well to be reminded that the scientific investigator is prone to take himself for granted and not to realise "what an altogether astonishing and even grotesque mystery he and his doings constitute" for the general mass of social human beings.

"Co-operation and the Problem of Unemployment " is the title of a pamphlet issued last month by the Calcutta newspaper Capital, being a reprint of a series of articles contributed by Captain J. W. Petavel, Principal of Maharajah Kasimbazar's Polytechnic Institute, together with correspondence between Captain Petavel and the Vice-Chancellor of the Calcutta University. The recent establishment by this university of a Poverty Problem Study Fund, to meet the cost of lectures and publications devoted particularly to the exploitation of a definite scheme of social reform, constitutes a new departure in university policy in regard to research in applied sociology. This scheme " to organise the children and the adolescents in schools and continuation schools, so as to make them form the trunk of a great tree of cooperative production and exchange, whose branches will extend in all directions and carry health into every part of our social system," is not new. Among its earliest supporters were the late Lord Roberts and Sir Horace Plunkett. Of late "economists and educationists in almost every part of the world," says the Vice-Chancellor of Calcutta University, have been canvassed, with the result that there has been a steadily increasing volume of opinion in favour of the scheme, and steps are being taken towards operating a large-scale trial application of it in schools in Bengal by means of self-supporting school market-gardens and school workshops. The experiment cannot fail to arouse keen interest, not only in India but wherever attempts are being made to extend and improve education without increasing its cost.

NO. 2756 , VOL. I IO]

\section{Calendar of Industrial Pioneers.}

August 27, I898. John Hopkinson died.-Distinguished as an engineer and a mathematical physicist, Hopkinson was a graduate of Trinity College, Cambridge, and in $187 \mathrm{I}$ was senior wrangler and Smith's prizeman. For some years he was scientific adviser to Messrs. Chance, of Birmingham, and made improvements in lighthouse apparatus. As a consulting engineer in London he took up the study of electrical problems; in 1882 patented the three-wire system, and four years later, with his brother Edward, published an important memoir on the principles of the design of dynamos. In I 890 he became professor of electrical engineering at King's College, London, and on two occasions served as president of the Institution of Electrical Engineers. His death was the result of an Alpine accident.

August 27, r9r4. William Thomas Lewis, Lord Merthyr of Senghenydd, died.-Coal owner, iron master, steel maker, engineer, and a captain of industry, Lewis began life as an apprentice in a South Wales engineering works. In I86o he became mining engineer to the estates of the Marquis of Bute, and twenty years later was made sole manager. He was a pioneer in the construction of stecl works.

August 3I, I75I. Christopher Polhem died.-A famous mining engineer of Sweden, Polhem was born in 1661 , in 1693 became engineer of the mines at Fahlem, and in I716 was raised to the nobility and was made a member of the council of mines. $\mathrm{He}$ travelled extensively, carried out important engineering works, and was one of the original members of the Academy of Sciences of Stockholm.

August 3I, 1865. John George Appold died.-After amassing a considerable fortune as a fur skin dyer, Appold turned his attention to mechanical pursuits and at the Great Exhibition of $185 \mathrm{I}$ attracted attention by his centrifugal pump. Among his other inventions was the brake used in connexion with the laying of the first Atlantic cable.

September 2, 1834. Thomas Telford died.-The son of a shepherd of Eskdale, Dumfries, Telford was born on August 9, I757. Apprenticed to a mason, he afterwards worked in Edinburgh, London, and Portsmouth, became surveyor of public works in Shropshire, engineer of the Ellesmere Canal, and in Scotland built the Caledonian Canal and opened up the country by the construction of 920 miles of roads and of 120 new bridges. Many other bridges, canals, and harbour schemes were due to him, and among these were the Gotha Canal between the Baltic and North Sea and the famous suspension bridge over the Menai Straits. An acknowledged leader in the world of civil engineering, in $x 818$ he bccame the first president of the Institution of Civil Engineers and held that position till his death. He died at 24 Abingdon Street, Westminster, and was buried in the nave of Westminster Abbey. His statue stands in the Chapel of St. Andrew.

September 2, 1883. Cromwell Fleetwood Varley died.-One of the pioneers of the Atlantic Telegraph Cable, Varley as a boy entered the service of the Electric and International Telegraph Company and of this firm became engineer-in-chief. After the failure of the first Atlantic cable he constructed an experimental line for studying the phenomena of signalling, and during I864-5 tested the whole of the new cable for the Atlantic Telegraph Company. Retiring from active work in 1868 , he continued his investigations and in $x 870$ transmitted musical sounds over an ordinary telegraph wire.
E. C. S. 